\title{
Program Penguatan dan Pe ndampingan Aspek Psikologis Relawan Bencana Covid 19
}

\section{Psychological Aspect Strengthening and Assistance Program Covid Disaster Volunteers 19}

\author{
Ike Mardiati Agustin ${ }^{1 *}$, Nurlaila ${ }^{2}$, Yulia $^{3}$ \\ 1,2STIKES Muhammadiyah Gombong \\ ${ }^{3}$ Rumah Sakit DR Soedirman Kebumen \\ *Corresponding author : ikemardiati@stikesmuhgombong.ac.id
}

\begin{abstract}
Kata Kunci: Pandemi; Covid 19;

Relawan bencana; kondisi Psikologis; Program

\section{ABSTRAK}

Indonesia bahkan Dunia saat ini sedang berada dalam masa berduka akibat adanya Pandemi Covid 19. Pandemi ini merupakan bencana non alam. Dibutuhkan peran serta masyarakat dalam upaya pencegahan dan penanganannya salah satunya dengan menjadi relawan bencana. Kondisi bencana akan memberikan berbagai dampak fisik maupun psikologis bagi setiap individu tidak terkecuali bagi relawan bencana. Tujuan kegiatan ini untuk menguatkan psikologis relawan bencana. Metode Program ini diberikan kepada 72 relawan bencana covid 19 yang merupakan gabungan dari relawan bencana BPBD kabupaten kebumen dan relawan bencana STIKES Muhammadiyah Gombong. Kegiatan yang dilakukan selama 2 bulan yaitu bulan Maret-April 2020 , meliputi 2 (dua) tahap yaitu tahap persiapan pra penugasan diawali dengan melakukan pengukuran kondisi psikologis relawan bencana menggunakan instrument DASS (Depresion Anxiety Stres Scale), dan melalui pemberian psikoterapi untuk mengatasi masalah psikologis yang muncul. Hasil kegiatan didapatkan gambaran sebelum dan setelah diberikan program penguatan dan pendampingan aspek psikologis relawan bencana covid 19 bahwa kondisi psikologis relawan dari ansietas ringan sebanyak 68 orang $(94,44 \%)$ menjadi normal sebanyak 69 orang $(95,83 \%)$, dari depresi ringan sebanyak 69 orang $(95,83 \%)$ menjadi normal sebanyak 70 orang $(97,22 \%)$ dan dari stres ringan sebanyak 69 orang $(95,83 \%)$ menjadi normal sebanyak 70 orang $(97,22 \%)$. Kesimpulan melalui kegiatan ini terjadi penguatan aspek psikologis relawan bencana covid 19. Kegiatan ini direkomendasikan untuk program berkelanjutan bagi penguatan psikologis relawan bencana.
\end{abstract}

Kata Kunci: Pandemic; Covid 19; disaster volunteer; psychological Condition; Programs

\begin{abstract}
ABSTRAK
Indonesia and even the world are currently in grief due to the Covid 19 Pandemic. This pandemic is a non-natural disaster. Community participation is needed in efforts to prevent and handle one of them by becoming a disaster volunteer. Disaster conditions will have various physical and psychological impacts for each individual, including disaster volunteers. The purpose of this activity is to strengthen the psychology of disaster volunteers. This program method was given to 72 covid 19 disaster volunteers who were a combination of BPBD disaster volunteers in Kebumen district and STIKES Muhammadiyah Gombong disaster volunteers. Activities carried out for 2 months, namely March-April 2020, include 2 (two) stages, namely the pre-assignment preparation stage starting with measuring the psychological condition of disaster volunteers using the DASS (Depresion Anxiety Stress Scale) instrument, and through providing psychotherapy to overcome psychological problems. emerging. The results of the activity obtained an overview before and after being given a strengthening and assistance program for the psychological aspects of covid 19 disaster volunteers that the psychological condition of volunteers from mild anxiety was 68 people $(94.44 \%)$ to normal as many as 69 people $(95.83 \%)$, from mild depression as many as 69 people $(95.83 \%)$ became normal as many as 70 people $(97.22 \%)$ and from mild stress as many as 69 people $(95.83 \%$ ) became normal as many as 70 people $(97.22 \%)$. The conclusion
\end{abstract}


is that through this activity there is a strengthening of the psychological aspects of covid 19 disaster volunteers. This activity is recommended for a sustainable program for psychological strengthening of disaster volunteers

\section{PENDAHULUAN}

Indonesia bahkan Dunia saat ini sedang berada dalam masa berduka akibat adanya Pandemi Covid 19. Pandemi ini merupakan bencana non alam. WHO (2020) Telah menyatakan bahwa pandemic covid 19 ini dapat meningkatkan stres pada seluruh lapisan masyarakat.

Kondisi bencana non alam yang luas dan menyeluruh seperti saat ini membutuhkan peran serta semua lapisan masyarakat dalam upaya pencegahan maupun penanganannya. Peran serta masyarakat yang dapat dilakukan salah satunya dengan menjadi tenaga relawan bencana . Relawan adalah seorang atau sekelompok orang yang memiliki kemampuan dan kepedulian untuk bekerja secara sukarela dan ikhlas dalam upaya penanggulangan bencana (BNPB 2014). Seorang relawan bencana di tuntut memiliki kemampuan Cepat dan tepat, mampu melakukan prioritas tindakan, mampu berkoordinasi, Berdaya guna dan berhasil guna, Transparansi, Akuntabilitas, mampu menjalin kemitraan, Pemberdayaan, Non diskriminasi, selama menjadi relawan tidak menyebarkan agama, menjunjung kesetaraan gender dan menghormati kearifan lokal (BNPB, 2014).

Kondisi bencana akan memberikan berbagai dampak fisik maupun psikologis bagi setiap individu tidak terkecuali pada relawan bencana. Relawan bencana merupakan kelompok rentan yang dapat mengalami masalah fisik maupun psikologis, berbagai kegiatan penanganan bencana non alam yaitu wabah covid 19 ini menimbulkan respon psikologis yang beragam bagi tenaga kesehatan yang harus merawat pasien covid 19 maupun relawan yang bertugas membantu pemerintah dalam penanganan bencana covid 19, beberapa respon psikologis yang muncul yaitu emosi negatif seperti kelelahan, ketidaknyamanan, dan ketidakberdayaan disebabkan oleh pekerjaan intensitas tinggi, ketakutan dan kecemasan, dan kepedulian terhadap pasien dan anggota keluarga. Koping individu termasuk penyesuaian psikologis dan kehidupan, tindakan altruistik, dukungan tim, dan kognisi rasional.Respon psikologis yang bersifat negative berkembang bersama respon psikologis yang bersifat positif (Sun et al. 2020).

Masalah psikologis lain yang dapat dialami seorang relawan bencana adalah rasa stres selama menjalani aktivitas sebagai relawan, hal ini didukung oleh hasil penelitian (Permatasari dan Ariati, 2015) yang menyatakan bahwa stres dapat 
dialami oleh seorang relawan bencana PMI dengan gejala yang ditimbulkan mudah tersinggung, mudah marah. Penelitian lain menyebutkan bahwa respon psikologis juga dilaporkan oleh relawan dari Uni Eropa saat adanya wabah penyakit virus Ebola terbesar yang pernah dimulai di Afrika Barat pada Desember 2013. Respon spikologis relawan menunjukan bahwa relawan merasa ketakutan akan terinfeksi dan khawatiran akan menginfeksi keluarga mereka. (Belfroid et al. 2018).

Masalah psikologis yang dialami relawan tidak hanya datang dari dalam dirinya sendiri, namun karena rendahnya dukungan keluarga terhadap aktivitas relawan tersebut, hasil penelitian terhadap relawan wabah penyakit virus Ebola menunjukan sebanyak 50\% keluarga relawan melaporkan bahwa mereka khawatir relawan akan terinfeki virus ebola (Belfroid et al. 2018).

$$
\text { Pada penelitian lain }
$$
menyebutkan bahwa pengalaman relawan bencana meliputi memiliki motivasi menolong sesuai dengan bidang keahliannya serta fasilitas umpan balik yang dia dapatkan selama dan setelah menjalankan tugas relawan. Perasaan takut mati juga disampaikan oleh relawan bencana sehingga menghasilkan persiapan kognitif, emosi positif maupun emosi negatif (Ratri and Masykur 2019).

$$
\text { Berdasarkan fenomena }
$$
tersebut, dibutuhkan suatu bentuk kegiatan yang mampu menguatkan psikologis seorang relawan bencana yang dilakukan dalam 2 (dua) tahap (Pra penugasan, dan saat penugasan) hal ini mengacu pada pedoman dukungan kesehatan jiwa dan psikososial bagi relawan bencana (KEMENKES R1, 2020) yang didalamnya mengatur tentang upaya memberikan dukungan kesehatan jiwa dan psikososial bagi relawan bencana covid 19. Sebagai bentuk implementasi kegiatan tersebut dilakukan pengabdian masyarakat dalam bentuk Program Penguatan dan Pendampingan Aspek Psikologis Relawan Bencana Covid

\section{METODE}

Program ini diberikan kepada 72 relawan bencana covid 19 yang merupakan gabungan dari relawan bencana BPBD kabupaten kebumen dan relawan bencana STIKES Muhammadiyah Gombong.

Kegiatan yang dilakukan selama 2 bulan yaitu bulan maret-april 2020 , kegaitan program ini meliputi 2 tahap yaitu tahap persiapan pra penugasan diawali dengan melakukan pengukuran kondisi psikologis relawan bencana menggunakan instrument DASS (Depresion Anxiety Stres Scale), kemudian melakukan kegiatan pembekalan manajamen kecemasan, depresi dan stress dengan hipnotis lima jari, afirmasi positif , penguatan spiritual bagi relawan, serta pengecekan alat pelindung diri selama tugas menjadi relawan bencana wabah covid 19 . Tahap kedua adalah saat penugasan 
yaitu melakukan kegiatan berupa supervisi atau pendampingan relawan saat mereka menjalani penugasan. Kegiatan supervisi yang dilakukan berupa pemberian extra fooding untuk penguatan fisik dan imun relawan serta memberikan psikoterapi untuk manajemen kecemasan, depresi dan stres yaitu memberikan kesempatan pada relawan untuk mengungkapkan segala keluh kesah selama penugasan dalam bentuk refleksi dan ekspres feeling, memberikan terapi relaksasi nafas, hipnotis lima jari dikombinasi dengan terapi music dan melakukan terapi afirmasi positif untuk menguatkan psikologis relawan selama bertugas.

\section{HASIL DAN PEMBAHASAN}

Kegiatan pengabdian masyarakat ini dilakukan dalam 2 tahap yaitu tahap pra penugasan dan saat penugasan. Kegiatan pra penugasan dilakukan dengan memberikan penguatan berupa psikoterapi individu untuk mengatasi masalah psikologis relawan.

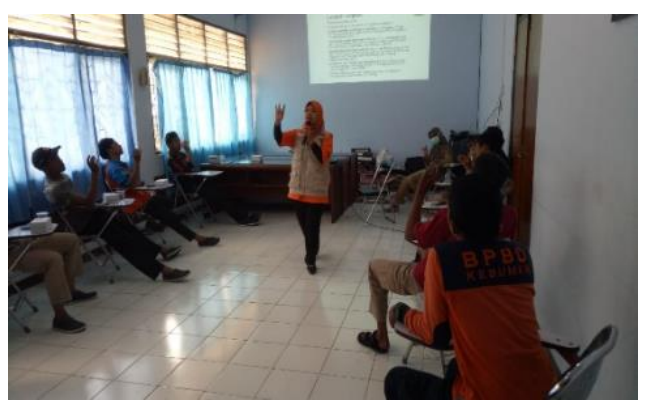

Gambar 1. Pelaksanaan Proses pembekalan pra penugasan

Tahap berikutnya adalah saat penugasan yaitu melakukan kegiatan berupa supervisi atau pendampingan relawan saat mereka menjalani penugasan. Kegiatan supervisi yang dilakukan berupa pemberian extra fooding untuk penguatan fisik dan imun relawan serta memberikan psikoterapi untuk manajemen kecemasan/anxiety, depresi dan stres yaitu memberikan kesempatan pada relawan untuk mengungkapkan segala keluh kesah selama penugasan dalam bentuk refleksi dan ekspres feeling, memberikan terapi relaksasi nafas, hipnotis lima jari dikombinasi dengan terapi music dan melakukan terapi afirmasi positif untuk menguatkan psikologis relawan selama bertugas. 


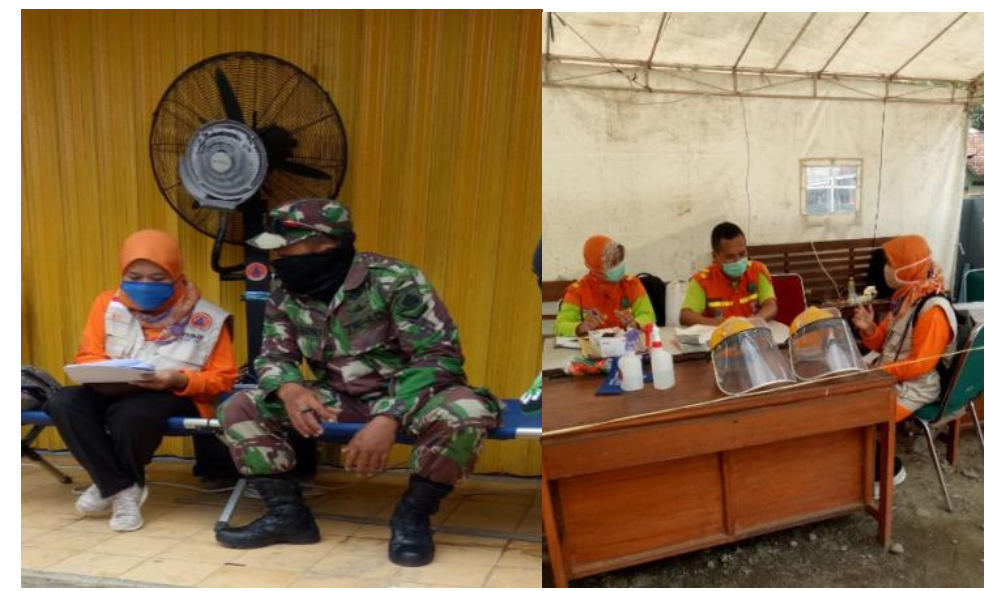

Gambar 2. Proses supervisi ditahap penugasan

Berdasarkan kegiatan tersebut, menunjukan hasil perubahan kondisi psikologis relawan sebelum dan sesudah dilakukan kegiatan Program Penguatan dan Pendampingan Aspek Psikologis Relawan Bencana Covid 19. Adapun hasil kegiatan di jabarkan dalam tabel sebagai berikut:

Tabel 1.1

Kondisi psikologis (Tingkat Ansietas) relawan bencana covid 19 Sebelum dan Sesudah mendapatkan program penguatan dan pendampingan aspek psikologis

$(\mathrm{N}=72)$

\begin{tabular}{ccccc}
\hline Tingkat & \multicolumn{2}{c}{ Pre Test } & \multicolumn{2}{c}{ Post Test } \\
Ansietas & Jumlah & Prosentase & Jumlah & Prosentase \\
Normal & 0 & 0 & 69 & 95,83 \\
Ringan & 68 & 4,44 & 2 & 2,78 \\
Sedang & 3 & 1,39 & 1 & 1,39 \\
Berat & 1 & $\mathbf{1 0 0}$ & 0 & 0 \\
Jumlah & $\mathbf{7 2}$ & $\mathbf{7 2}$ & $\mathbf{1 0 0}$ \\
\hline
\end{tabular}

Berdasarkan Tabel 1.1 diatas dapat diketahui bahwa terjadi perubahan kondisi psikologis relawan (tingkat ansietas) sebelum dan setelah diberikan program penguatan dan pendampingan aspek psikologis relawan bencana covid 19 dari ansietas ringan sebanyak 68 orang $(94,44 \%)$ menjadi ansietas normal sebanyak 69 orang $(95,83 \%)$. 


\section{Tabel 1.2}

Kondisi psikologis (Tingkat Depresi) relawan bencana covid 19 Sebelum dan Sesudah mendapatkan program penguatan dan pendampingan aspek psikologis

$(\mathrm{N}=72)$

\begin{tabular}{ccccc}
\hline Tingkat & \multicolumn{2}{c}{ Pre Test } & \multicolumn{2}{c}{ Post Test } \\
Depresi & Jumlah & Prosentase & Jumlah & Prosentase \\
Normal & 0 & 0 & 70 & 97,22 \\
Ringan & 69 & 95,83 & 2 & 2,78 \\
Sedang & 3 & 4,17 & 0 & 0 \\
Jumlah & $\mathbf{7 2}$ & $\mathbf{1 0 0}$ & $\mathbf{7 2}$ & $\mathbf{1 0 0}$ \\
\hline
\end{tabular}

Berdasarkan Tabel 1.2 diatas dapat diketahui bahwa terjadi perubahan kondisi psikologis relawan (tingkat depresi) sebelum dan setelah diberikan program penguatan dan pendampingan aspek psikologis relawan bencana covid 19 dari depresi ringan sebanyak 69 orang $(95,83 \%)$ menjadi normal sebanyak 70 orang $(97,22 \%)$.

\section{Tabel 1.3}

Kondisi psikologis (Tingkat Stres) relawan bencana covid 19 Sebelum dan Sesudah mendapatkan program penguatan dan pendampingan aspek psikologis

$(\mathrm{N}=72)$

\begin{tabular}{ccccc}
\hline Tingkat & \multicolumn{2}{c}{ Pre Test } & \multicolumn{2}{c}{ Post Test } \\
Depresi & Jumlah & Prosentase & Jumlah & Prosentase \\
Normal & 0 & 0 & 70 & 97,22 \\
Ringan & 69 & 95,83 & 2 & 2,78 \\
Sedang & 3 & 4,17 & 0 & 0 \\
Jumlah & $\mathbf{7 2}$ & $\mathbf{1 0 0}$ & $\mathbf{7 2}$ & $\mathbf{1 0 0}$ \\
\hline
\end{tabular}

Berdasarkan Tabel 1.2 diatas dapat diketahui bahwa terjadi perubahan kondisi psikologis relawan (tingkat stres) sebelum dan setelah diberikan program penguatan dan pendampingan aspek psikologis relawan bencana covid 19 dari stres ringan sebanyak 69 orang $(95,83 \%)$ menjadi normal sebanyak 70 orang $(97,22 \%)$.
Dikaitkan dengan hal tersebut hasil kegiatan ini menunjukan bahwa terdapat pengaruh pemberian psikoterapi individu dalam program pendampingan dan penguatan aspek psikologis terhadap tingkat ansietas, depresi dan stres pada relawan bencana covid 19, hal ini sejalan dengan hasil penelitian Pinilih, Astuti, dan Amin (2014) pada penderita depresi yang diberikan psikoterapi 
individu berupa afirmasi positif efektif dapat merubah pikiran negatif seseorang. Pemberian psikoterapi untuk mengatasi kecemasan sangat efektif dilakukan sejalan dengan Penelitian yang dilakukan Banon, Dalami, dan Noorkasiani (2014); Astuti, Marsito, dan Sumarsih (2017) tentang efektivitas penerapan psikoterapi individu menunjukkan adanya penurunan kecemasan yang signifikan pada pasien hipertensi setelah diberikan terapi individu, nafas dalam dan hipnosis lima jari.

Program pendampingan

relawan yang dilakukan sejalan

\section{SIMPULAN}

Melalui program ini didapatkan gambaran sebelum dan setelah diberikan program penguatan dan pendampingan aspek psikologis relawan bencana covid 19 bahwa kondisi psikologis relawan dari ansietas ringan sebanyak 68 orang (94,44\%) menjadi normal sebanyak 69 orang $(95,83 \%)$, dari depresi ringan sebanyak 69 orang $(95,83 \%)$ menjadi normal sebanyak 70 orang $(97,22 \%)$ dan dari stres ringan sebanyak 69 orang $(95,83 \%)$ menjadi normal sebanyak 70 orang $(97,22 \%)$.

Rencana tindak lanjut dari program ini adalah adanya supervisi dari tenaga kesehatan jiwa sesuai dengan kompetensinya, tetap memberikan kesempatan pada relawan untuk terhubung dengan keluarga atau orang dengan kebijakan yang diterapkan oleh KEMENKES RI, 2020 tentang dukungan kesehatan jiwa dan psikososial bagi relawan antara lain memberikan pelatihan yang memadai tentang kesiapan diri untuk menjadi relawan bencana, adanya supervisi dari tenaga kesehatan jiwa sesuai dengan kompetensinya, tetap memberikan kesempatan pada relawan untuk terhubung dengan keluarga atau orang terdekat lainnya, membuat support grup antar relawan untuk saling menguatkan satu dengan yang lainnya. terdekat lainnya, membuat support grup antar relawan untuk saling menguatkan satu dengan yang lainnya

\section{DAFTAR PUSTAKA}

Ayu Rahmawati Permatasari, Jati Ariati. Efikasi diri dan Stres kerja pada Relawan PMI Kabupaten Boyolali, Jurnal Empati, Oktober 2015. Volume 4 (4) 239-244. https://ejournal3.undip.ac.id/inde x.php/empati/article/view/14349. Diakses tanggal 29 mei 2020

Belfroid, Evelien et al. 2018. "Positive Experiences of Volunteers Working in Deployable Laboratories in West Africa during the Ebola Outbreak." PLOS ONE 13(4): 1-8.

BNPB. 2014. Berita Negara Republik Indonesia Penanggulangan Bencana Pedoman. https://bnpb.go.id/. 
Inter Agency Standing Committee (IASC). 2020. Catatan Tentang Aspek Kesehatan Jiwa dan Psikososial Wabah Covid-19 Versi 01.

Kementrian Kesehatan RI, 2020. Pedoman Dukungan Kesehatan Jiwa dan Psikososial pada Pandemi Covid 19. Jakarta

Keliat, Budi Anna,dkk. 2020. Pedoman Dukungan Kesehatan Jiwa dan Psikososial pada Pandemi Covid 19. Jakarta. Ikatan Perawat Kesehatan Jiwa Indonesia

Marsito. (2017). Pengaruh Hipnosis lima jari terhadap tingkat kecemasan lansia hipertensi di wilayah Puskesmas Sempor 1 Kabupaten Kebumen. STIKES Muhammadiyah Gombong. Diambil dari http://elib.stikesmuhgombong.ac .id/557/1/ARUM DWI ASTUTI
NIM. A11300861.pdf

Noorkasiani, B. D. (2014). Efektivitas Terapi Hipnosis Lima Jari untuk Menurunkan Tingkat Ansietas Pasien Hipertensi. Poltekkes Kemenkes Jakarta III.I

Ratri, Edith Dewani Anggarit, and Achmad Mujab Masykur. 2019. "Para Pengibar Kemanusiaan (Analisis Fenomenologi Interpretatif Tentang Pengalaman Menjadi Relawan Bencana LakiLaki)." Empati 8(4): 148-61.

Sun, Niuniu et al. 2020. "A Qualitative Study on the Psychological Experience of Caregivers of COVID-19 Patients." AJIC: American Journal of Infection Control. https://doi.org/10.1016/j.ajic.202 0.03.018. 